\title{
ZHUANGZI AND HIS
BUTTERFLY DREAM: THE ETYMOLOGY OF MENG 夢 Jingjing Chen
}

$\mathrm{I}^{\mathrm{N}}$

ZHUANGZI 莊子, an ancient Chinese text written by Daoist philosopher Zhuangzi during the late Warring States period (476-221 BCE), a story tells that Zhuang Zhou once dreamed he was a butterfly, flitting and fluttering around, happy, and doing as he pleased. As a butterfly, he did not know he was Zhuang Zhou. All of a sudden, he awoke and found he was Zhuang Zhou, solid and unmistakably human. But then he did not know whether he was Zhuang Zhou dreaming he was a butterfly or a butterfly dreaming he was Zhuang Zhou. In the end, Zhuangzi wrote, there was necessarily a difference between Zhuang Zhou and the butterfly; this difference was the 'transformation of things'物化. The transformation is a change in consciousness between reality and illusion. The constant flux between dreams and awakening leads the 'self' to change from being unaware of the distinction of things to being aware of the definite distinction between and among things.

Zhuangziis one of the foundational texts of Chinese literature and philosophy. Later interpretations of dreams in the Chinese literary tradition drew on this strange and radical story. Much discussion has focused on the nature of the atmosphere Zhuangzi created for this 'butterfly dream', and whether it was inherently optimistic or pessimistic. Two contrasting interpretative traditions have evolved: one drawing on the image of the carefree butterfly that hinted at a 
bright and soaring future; the other gloomy and melancholy, leading to a reading of 'life is but a dream'.

Despite the contrast in these perspectives, both traditions have based their interpretations of the dream in the worldly realm. By reinterpreting the dream in a worldly frame of displacement in space and time, they moved away from Zhuangzi's contemplation of the question of agency, initiative, and the 'distinction' 分 of things.

Over the centuries, the optimistic school gained the upper hand in emphasising the butterfly image in Zhuangzi's dream. Chinese scholars and poets tended to refer to Zhuangzi's butterfly dream as if it were a fixed allusion for a delightful experience. It was assimilated to descriptions of a happy existence and expressions of self-content. For example, Su Shi 蘇軾, an eminent scholar and official of the eleventh-twelfth centuries also known as Su Dongpo 蘇東坡, alluded to Zhuangzi in a poem describing a wonderful dream he had while living in the mountains. Su wrote: 'I am unaware of the bell and drum announcing the break of dawn; in my dreams I am a joyful butterfly, carefree’ 不知鐘鼓報天明，夢裹栩然蝴 蝶, 一身輕.

The more melancholy imagining of the dream - and of dreams in general - as hazy and chaotic is founded on the etymology of the character meng 夢 (梦 in simplified characters), meaning 4 多 'dream'. In its earliest appearance in the written record, the character resembled the movements of a person's eyebrows, eyes, and limbs while dreaming. Later, the radicals (the graphic components of a character that function as semantic or phonetic indicators) 'roof' $\rightarrow$ and 'evening' 夕 were added. Under the Han dynasty, the character was simplified and standardised in 'small-seal' script as 帒, similar to the modern 夢. Before the standardisation, one of most common formations of the character was 献, which comprises other semantic radicals related to 'dream'. It is worth noting that despite variations in the form of the character due to the choice of differing radicals, the graphs for a house's roof and the sun at dusk - representing dimness and darkness in a restrained space - have always figured in its main semantic form.

One of the lines in the Book of Songs 詩經 (eleventh-seventh centuries BCE), in which meng 


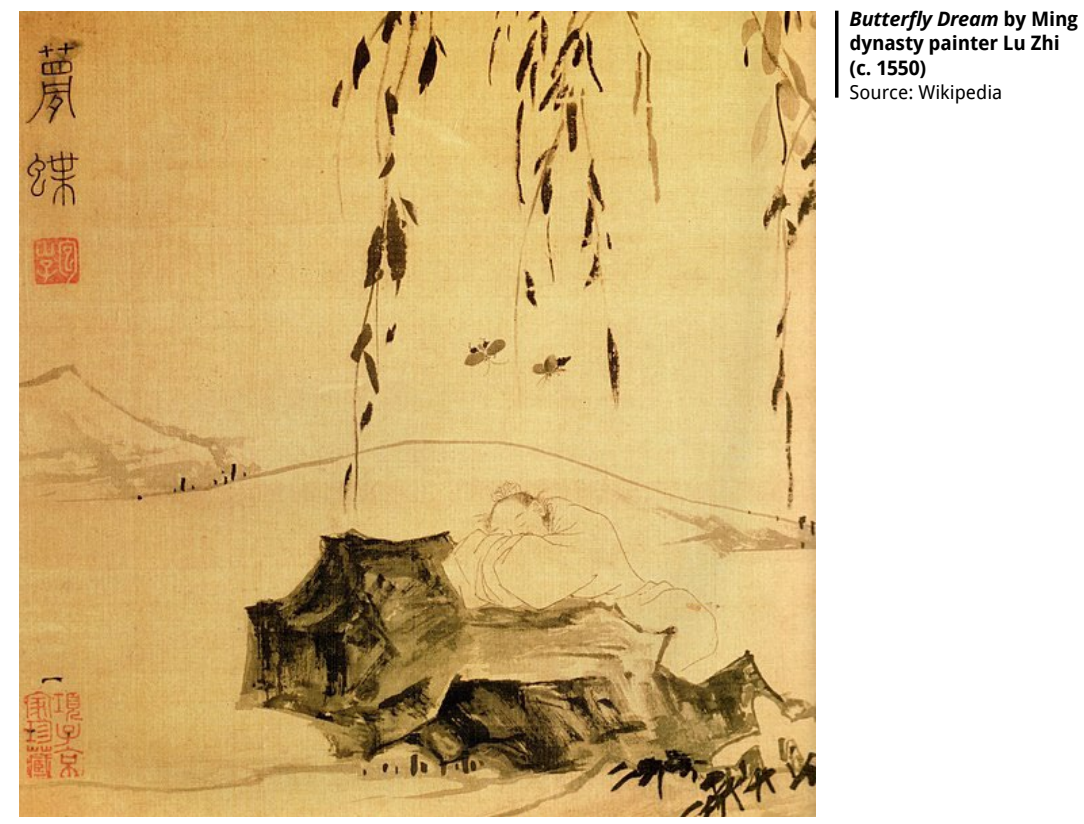

appears, reads: 'When I see you so mengmeng, my heart is full of pain' 視爾夢夢, 我心惨慘. Here, meng implies 'dark' or 'confused'. Readings of meng expanded to include dimness, gloominess, and even chaos in a dark environment. In commentaries of the Han dynasty, the character was restricted solely to descriptions of the mood of an individual. From the Tang dynasty of the eighth century, it pointed to an interaction with the wider world and extended to descriptions of murkiness and disorder in society. Since this time, classic exegesis began using the character meng in descriptions of the unresolved and chaotic politics of the imperial court.

After the thirteenth century, scholars became less likely to interpret meng as being closely tied to the meaning of its component radicals, but they still understood it in the context of worldly life. They referred more to how dreams reflect the displacement of time and space. The literature of late imperial China (1368-1911) included many works with 'dream' in the title, exploring dreams as memories of 
life in the past. Many such works were written by members of the nobility whose families had declined, sometimes in parallel with dynasties or societies as a whole, and who no longer enjoyed a privileged lifestyle. Here, the dream became a metaphor for a forever-lost life (and its material pleasures) - a lament for displacement in space and time. Notable examples are Dream Recollections of Tao'an 陶庵夢憶 and Searching for the West Lake in Dreams 西湖夢寻 by Zhang Dai 張岱 after the fall of the Ming in 1644, and The Dream of the Red Chamber 紅樓蓦, written by Cao Xueqin 曹雪芹 and published in 1791, after a marked decline in his family's fortunes when the Qing dynasty itself was beginning to decay after having reached its high point in the late eighteenth century (see Introduction Forum 'From the Land of Illusion to the Paradise of
Truth', pp.5-9). These and other works drew on sentiments from Zhuang Zhou's dream but tied the idea of the dream to material existence. Metaphysical discussions of Zhuangzi's final question about the blurring of divisions, the so-called transformation of things, and the pursuits of spiritual existence, were seldom mentioned.

The current meng 夢 in the China Dream 中國夢 is a modern concept, a cherished aspiration and an ideal dream 夢想 that do not really capture the past ideas of dreams in Chinese texts such as Zhuangzi. The phrase of the China Dream itself, linguistically speaking, is a calque or loan translation following the word construction of meiguo meng 美國夢, translated from the American Dream. Thus, in the modern period, the character meng takes on new meanings by connecting China to the cosmopolitan world. 
This text is taken from China Story Yearbook: China Dreams, edited by Jane Golley, Linda Jaivin, Ben Hillman and Sharon Strange, published 2020 by ANU Press, The Australian National University, Canberra, Australia.

doi.org/10.22459/CSY.2020.00B 